\title{
SINO-RUSSIAN COMPETITIVE COLLABORATION FOR THE CENTRAL ASIAN SPHERE OF INFLUENCE
}

\author{
Muhammad Nadeem Mirza and Shaukat Ayub
}

Quaid-i-Azam University

\begin{abstract}
With the signing of several lucrative deals on oil, gas, currency, and other bilateral and multilateral arrangements, Sino-Russian relations over the last three decades have reached unprecedented levels. However, as China begins to translate its economic influence in Central Asia into political one, Russia started feeling uneasy about losing its traditional sphere of influence in its 'Near-Abroad.' After the unveiling of 'One Belt One Road' (OBOR) initiative in 2013, President Putin, a year later, announced the 'Eurasian Economic Union' (EAEU). This was a calculated geopolitical decision on the part of Russia to rescue Central Asia from falling entirely in the Chinese sphere of influence. Against this backdrop, the regional order invites a deep sense of mistrust because there is a lack of realization on the part of both states as to where one's limits end and the other's begin. In the light of these developments, this study endeavors to address the question that why is Russia allowing China to expand its influence in Central Asia despite the growing economic asymmetry between them and what are the areas of convergence and divergence between them? The study hypothesizes that China and Russia have adopted the policy of competitive collaboration - cooperation where there exists convergence and competition when it comes to divergence of interests - in Central Asia.
\end{abstract}

Keywords: near-abroad, New Great Game, geopolitics, pipeline politics, Central Asia, China, Russia

DOI: https//doi.org/10.3176/tr.2021.4.04

Received 7 August 2021, accepted 20 September 2021, printed and available online 10 December 2021 


\section{Introduction}

Central Asia, through most part of its history, has remained a theatre of geostrategic and geo-economic competition between great powers of the time. Demise of the Soviet Union in 1990s accelerated this competition for the control of energy resources of Central Asia and the adjacent Caspian Sea region as an alternative to diversify global oil's supply and demand equation vis-à-vis the North Sea and the Persian Gulf (Blank 1995). Moreover, part of the contestation was over the pipeline politics. The routes which were supposed to be taken out of the region determined, in large parts, the competition between Russia and the West over getting Central Asia's oil and gas. However, over the last few decades there is a new player in the town. China is now extracting most of the resources which were previously going to the West are now heading towards the East. Traditionally, most of the natural resources in Central Asia and the Caspian Sea remained under Russia's control which meant that Moscow was in the driving seat. Most of the pipelines were developed by the Soviet Union, to meet the demands of the industrialised states of Western Europe (Hart 2016).

As China entered the region with substantial economic incentives, many Russian observers started feeling perturbed about the gradual loss of its sphere of influence. This is evident from the fact that immediately after unveiling of 'One Belt One Road' (OBOR) by China in 2013, Russia announced its own regional economic organisation known as the 'Eurasian Economic Union' (EAEU) in 2014 (EAEU 2014). The union incorporates Russia, Kyrgyzstan, Kazakhstan, Armenia, and Belarus. It has been interpreted as a Russian attempt to thwart outsiders' influence and to bring itself closer to the region. This fact is further reinforced by Russia's proposal to forge a free-trade agreement between Eurasian Economic Union (EAEU) and India by the end of 2020; this seems to be a calculated Russian move to balance China's ambitions designs in the region (Jiang 2020).

For China, Central Asia stands out as a strategic bridge between Europe and itself especially in the light of 'Belt and Road Initiative' (BRI) which has become a vital springboard for 'Go West' (Harper 2019: 100) initiative, unveiled by President Xi Jinping in Kazakhstan back in 2013 (Jinping 2013). Besides having economic ambitions, China, due to its close geographical proximity, also considers Central Asia as a region of utmost concern particularly for its domestic security considerations. Beijing fears that any kind of instability in the region would not only undermine its admission ticket to Eurasia, let alone energy security, but could also undermine its struggle against what China calls the 'three evils' - a deadly combination of religious extremism, separatism, and above all, terrorism (Zhao Lei 2019). Russia, on the other hand, views Central Asia as part of its 'Near-Abroad' (Sahai 2019: 2). Russian leaders remain wary of the growing asymmetry in their relationship with China's increasing influence in the region - with whom is attached its normative prestige as a great power, and a long border. The leaders in Kremlin fear that massive Chinese investments will bring it closer to the Central Asian republics, at the expense of Russia's predominant position therein. 
The study is inspired by the contributions of Susanna Hast's theory of Sphere of Influence in her seminal work titled as 'Sphere of Influence in International Relations: History, Theory and Politics' published in 2014 (Hast 2014). A sphere of influence is a particular region dominated by a state, at the expense of its rival's influence. The dominant state continues to deny the rival state any opportunity to expand its influence. However, the rival state, in response, undertakes different strategies ranging from economic incentives to supporting dissenting voices and movements to undermine the dominant state's influence in that region (Mirza et al. 2021). This study, to a large extent, revolves around the conceptual understanding of the sphere of influence which in this case is Central Asia where China and Russia are competing yet collaborating with each other. Moreover, the study is mostly qualitative in nature with reliance on secondary data.

\section{Sino-Russian convergence of interests in Central Asia}

Central Asia is where the convergence of Sino-Russian interests can be seen through the regional multilateral organizations. SCO is the most notable example where Moscow and Beijing agree to tackle common threats and utilise common opportunities. The strategic partnership on a bilateral level between Russia and China in Central Asia and beyond creates scepticism making their partnership essentially "hostage to fortune" (Lo 2008: 6). However, events in the last few decades show that substantial efforts have been made in the direction of finding common grounds for cooperation as well as identifying areas where problems and issues related to cooperation are mitigated. This has further been augmented by the seeming arrangement where Beijing is carrying out economic and commercial activities while Moscow is trying to perform the role of regional policeman.

\section{Regional security: win-win cooperation}

The animosity between China and Russia lasted for almost three decades until 1990s. Since then, they are seen as drawing closer from being fierce belligerents to good neighbors. Menon considers this Sino-Russian rapprochement to be a "strategic convergence" (Menon 1997: 101). One example of this convergence can be viewed in Central Asia. China has consistently been reiterating its stance on stabilising the Central Asian region, both politically and socially, through development initiatives. Russia, along the line, has been supporting these initiatives since it serves Moscow's interest to develop the region in order to counter fundamentalist groups located in Central Asia (Menon 2003). China has also been largely preoccupied with domestic tensions in its Xinjiang province which is home to the non-Han Chinese Uighur population of Turkic Muslims - descendent from the neighboring Central Asian republics. Officials in Beijing are concerned about this minority and suspect them of having links to the separatist and extremist groups (Stronski and Nicole 2018: 10). Thus, both Moscow and Beijing are drawn closer to cooperate in areas of common interests on the Central Asia theatre. 


\section{The formation of Shanghai Cooperation Organization}

The issues in Xinjiang led China to interpret domestic political stability as deeply interlinked with external threats emanating from Central Asia. This was one of the primary reasons behind the establishment of Shanghai Five (S-5) in 1996 which was later transmuted into Shanghai Cooperation Organization (SCO) in 2002 (Clarke 2010). Its founding members included China, Russia, Tajikistan, Kyrgyzstan, and Kazakhstan. This was initially set as a mechanism to create confidence building measures in order to address issues attached with the $7000 \mathrm{~km}$ long border between all the member states (Garnett 2001: 41).

From 1996-2000, the S-5 regional platform substantially aligned Russia's geopolitical threats in the region particularly emanating from the post-Soviet Afghanistan. In 1992 communist government was overthrown, and in 1996 Afghan Taliban captured Kabul. Through most of this era massive flow of weapons and drugs continued across Afghan borders. Russia had the fears of jihadists' resurgence in the newly born Central Asian republics emanating from Afghanistan which may spill over and create instability in Chechnya and other regions within the Russian Federation. Beijing too got worried of the rise of fundamentalism and the possible connection between Taliban and the Islamic Movement of Uzbekistan (IMU) and Hizb-ut-Tahrir (HT) whose ultimate aim remained to overthrow the regimes in their respective states (Rashid 2002: 137-156). Besides it feared that Taliban might support the Uyghur separatist movement in its Xinjiang province. The 1998 summit in Almaty, capital of Kazakhstan, via a joint declaration obliged all the member states to make sure that their respective territories are not used for activities related to undermining national sovereignty, jeopardizing national security, and eroding the socio-politico fabric of any of the five founding member states (Shanghai-5, 1998). This in turn manifested itself into a new framework of regional security also vital for domestic security of the states. Accordingly, this new regional security paradigm would ensure that common interests, security, and dialogue are pursued with a formal commitment of not entertaining other hierarchical alliances (Lanteigne 2005: 19).

Moreover, it was the 2001 Summit in Shanghai that transmuted the S-5 into another organization, Shanghai Cooperation Organization (SCO), with a new member, Uzbekistan. For Russia and China, it was an effort in relation with other regional states for strengthening their 'strategic partnership' to counterbalance any outside influence into the Russian sphere of influence and the Chinese economic interests in the region. The Chinese would extend its principles and call it "the Shanghai Spirit" based on "mutual benefit, mutual trust, equality, consultations, respect for each other's civilizations, and common development' (Clarke 2010: 6). The Shanghai Spirit, in other words, is best and commonly reflected in Five Cs: Communication, Confidence, Cooperation, Co-existence, and Common Interests (Chung 2004: 991). This was a milestone in the context of Sino-Russian relations in Central Asia as the convergence of interests endorsed Russians stance on Chechnya and the Chinese stance on Xinjiang, Taiwan, and Tibet ("Shanghai Five" Nations Sign Joint Statement 2000). 


\section{Keep the West at bay}

Both Russia and China share an element of dissatisfaction towards the existing world order established after the end of the Second World War. In the immediate aftermaths of the Second World War, the United States, having displaced Great Britain as a superpower, was in an exceptional position to create norms, rules, and international institutions which would help it and its allies achieve tremendous economic and political advantages. By the same token, despite numerous occasions when an all-out war seemed imminent, the United States and its allies left no stone unturned to ensure a continuity of the order. It is evident from the fact that there has almost been seven and a half decades without any great powers' war with each other. Moreover, the United States had persuaded and continues to persuade other countries to embrace the 'rules-based international order' (Allison 2018: 124-133). However, in the eyes of Russia and China it is a kind of order in which the the US and its allies make and often dictate the rules, while others are required to follow those rules (Shimbun 2017).

Looking at the current scenario, a major shift in the global distribution of power is transpiring in which rising China and resurgent Russia enjoy substantial influence around the world. They are not satisfied with the existing world order and have shown repeatedly the will and capacity to challenge it (Mirza and Khan 2020). The official foreign policy discourse of both states regarding many international issues usually involve denouncing western hegemony and emphasising multipolarity, while simultaneously strengthening their rapport with each other by signing of the 'strategic partnership' agreements and gradually drifting away from the West (Norling 2007: 33-36). Such a resolve has been reflected in the 'Sino-Russian Treaty on GoodNeighborliness, Friendship, and Cooperation' (2001) where both the countries have pledged to carry out efforts in promoting "a just and fair new world order" (Treaty of Good-Neighborliness and Friendly Cooperation Between the People's Republic of China and the Russian Federation 2001).

However, the geopolitical scenario changed drastically when the American-led coalition forces invaded Afghanistan in the pursuit of Al-Qaeda-Taliban nexus after the tragic incidents of September 11 2001. To carry out the combat operations in Afghanistan, the United States desperately needed military facilities in Central Asia. This was the primary objective which took precedence over democracy promotion, human or drug trafficking, and the pipeline politics (Romanowski 2017). Uzbekistan was one of the first Central Asian republics to grant bases at Karshi-Khanabad (K2) and Termez to US and coalition partners in their efforts to fight in Afghanistan and the provision of a supply-chain corridor near Afghan territory. Kyrgyzstan facilitated the coalition forces via its air base at Manas, and Kazakhstan allowed the US Air Forces to carry over-flight missions including refueling on its soil (Ahrari 2003: 164). Moreover, the United States poured large sums of money in Central Asia as part of the aid and lease agreements. In the fiscal year 2002, the US aid amounted 580 million dollars compared the previous year's 250 million dollars (Maynes 2003: 122123). The reason for facilitation of American and coalition forces in Uzbekistan and 
Kyrgyzstan was the willingness of the local regimes struggling against the Islamic Movement of Uzbekistan (IMU) and other extremist groups which they suspected of having ties to Al-Qaeda and the Taliban (Rashid 2002a: 137-186). The militant groups were particularly active in the volatile area of Ferghana Valley.

Paradoxically, the Russians had also calculated that the Americans presence in Afghanistan is for a shorter period of time and they will soon get the job done and will leave Afghanistan and Central Asia (Lo 2008: 94). But that turned out to be a miscalculated move as the Americans met fierce resistance from the Afghan fighters and found themselves entrenched in one of the longest wars in their history, which had the spill-over effects on Central Asia. This raised anxieties not only in Moscow but in the Beijing too. Those fears were intensified after the US invasion of Iraq in 2003 which led to the instability in the Middle East. Furthermore, the 'Color Revolutions' in Georgia, Ukraine, and Kyrgyzstan reinforced the long held beliefs in Moscow and Beijing of regime change policies largely supported by the United States and its allies (Lo 2008: 94).

\section{Sino-Russian divergence of interests in Central Asia}

There are little prospects of seeing any strategic competition in Central Asia between Russia and China in the near future. This, however, does not imply that the picture is as rosy as it looks. There is this element of imbalance or asymmetry in their relationship. As Russia is feeding China's energy appetite by exporting oil and gas as well as allowing Chinese capital to flow into the Russian markets, China is expanding its economic clout deep into the Russian backyard which could ultimately be translated into political and military influence (Mearsheimer 2016: 77-93).

Russia is well aware of the emerging geopolitical dynamics. The political elite in Moscow believes, given the history, that it is quite unlikely that China will pursue regional hegemony unless and until her geo-economic interests are jeopardised significantly. However, there is indeed a significant risk attached to it: the idea of neat division of geoeconomics from geopolitics is rather an idealistic and unrealistic one. Moisio "provide[d] a reading of "geoeconomics" from political geography that both evaluates geoeconomic claims on their own terms and, moreover, avoids a political/economy binary that even some of the critical approaches tend to fall into' (Moisio 2019). Expansion of geoeconomic influence almost always has geopolitical consequences.

\section{China: the leading trade partner in Central Asia}

The increasing cooperation between China and Russia in the realm of economy actually raises eyebrows in Moscow who is becoming a junior partner, being placed in a weaker position vis-à-vis Beijing in negotiations over favorable deals in Central Asia or elsewhere. Not having a choice, Russia looks to substitute those Western markets, after being denied access due to the sanctions, with that of the 
Chinese markets and investments. When it comes to bilateral trade with the Central Asian republics, Russia no longer remains the leading partner as it once used to be. According to the estimates in 2016, China has surpassed Russia as the former's total trade volume reached 30 billion dollars compared to the latter's 18.6 billion dollars with the region (Stronski and Nicole 2018: 14). Overall, Beijing is the dominant economic player in the region and continues to remain so in the foreseeable future. Moreover, if China's economic ventures bring prosperity and development to the region, it could be nothing short of playing a role of a benevolent regional hegemon. However, if it brings massive exploitations of the regional partners with no carrots as such then it could be a new chapter of imperial domination much the same way as it used to be in the previous centuries.

Currently, according to some statistics, China has become the largest trade partner with Turkmenistan and Kazakhstan, the next larger partner of Kyrgyzstan and Uzbekistan, and the third largest partner of Tajikistan. This makes up almost 75\% of China's total trade with the region (Huasheng 2013: 446). According to other estimates, China is interested to invest around 1 to 2 trillion dollars in Central Asia, future hub of natural resources (Shambaugh 2013: 174, 178, 181).Meanwhile, Moscow is very much concerned with China doing business ventures on bilateral basis with each Central Asian Republic. This has diminished Russian influence on the Central Asian chessboard where multilateral fora exist and where common objectives are pursued. Moreover, on the bilateral basis with China, the Russian economy mostly provides raw materials to the Chinese market as opposed to a manufacturing market that could also boost Russia's domestic industries.

As a result of the global financial crisis of 2008-2009 Moscow's share of investment and trade in the region declined substantially, while Beijing engagement in terms of trade and investments accelerated dramatically, particularly in Kazakhstan. The Chinese state-owned companies controlled up to $20 \%$ of Kazakhstan's natural gas and oil, not to mention numbers of local companies who received heavy debts from Chinese banks (Parkhomchik 2016). The Chinese-led initiatives resulted in strengthening of the asymmetry between Russian and China when it comes to Central Asia.

China, in order to facilitate and achieve its long-term goals, is heavily investing in a vast network of railways as transit routes for shipment of goods and services to Europe, and vice versa. The Central Asian republics will have access to East Asia via the China-Uzbekistan-Kyrgyzstan Railway (Muzalevsky 2012). China intends to extend the links to Europe, Middle East, and even Africa. All these railroads boil down to be part of China grand vision of 'Pan-Asian Railway' which is calculated to connect 7 countries in the Southeast Asia covering a total distance of $3000 \mathrm{~km}$ around the continent (Felicitas 2019). Interestingly, these railroads project are designed in such a clever move as to decrease China's traditional reliance on sea routes particularly the Indian Ocean and the Strait of Malacca where the Chinese commercial ships remain in a pretty vulnerable position vis-à-vis the US naval fleets - a phenomenon called Malacca Dilemma (Lanteigne 2008). It is estimated from the figures from the year 2011 that China imported almost 78 percent of oil from the Middle East via the Strait of Malacca (Shambaugh 2013: 163). 
Table 1. China's and Russia's trade with Central Asia

\begin{tabular}{lccc}
\hline & $\begin{array}{c}\text { Bilateral trade with } \\
\text { Russia }\end{array}$ & $\begin{array}{c}\text { Bilateral trade with } \\
\text { China }\end{array}$ & $\begin{array}{c}\text { China's rank among } \\
\text { Central Asian countries }\end{array}$ \\
\hline Kazakhstan & $\$ 12.9$ billion & $\$ 12.5$ billion & 2 \\
Uzbekistan & $\$ 2.7$ billion & $\$ 3.6$ billion & 1 \\
Turkmenistan & $\$ 902$ million & $\$ 5.9$ billion & 1 \\
Kyrgyzstan & $\$ 1.2$ billion & $\$ 5.7$ billion & 1 \\
Tajikistan & $\$ 688$ million & $\$ 1.8$ billion & 3 \\
\hline
\end{tabular}

Source: Data from 'World Integrated Trade Solution' Available online at $<$ https://wits.worldbank.org $>$. Accessed on 07.08.1921.

Interestingly, these projects bypass the Russian territory. Also, another nightmarish scenario for Russia is the 'Northern Route' which links Chinese Xinjiang region with Europe and passes through Kazakhstan, Russia, and Belarus. The problem remains that this route bypasses and challenges the Trans-Siberian Railway from which Russia earns substantial amount of resources. Moreover, there is this 'Southern Route' as well that goes through Kazakhstan and Turkmenistan all the way down to Iran. This too raised anxieties in Moscow as Kazakhstan stands out to be at clearer advantage after having the honor to host all these Chinese transit routes using its territory and that too being the member of EEU which officials in the Kremlin interpreted as a clever move to break EEU's unified front (Gabuev 2016: 75).

\section{Pipeline politics: the New Great Game}

The term 'New Great Game' came on spotlight of geopolitics after the breakup of the Soviet Union in 1990s. However, it is often associated with a Pakistani journalist and author Ahmad Rashid who introduced this "New Great Game" expression in the 1990s (Abbas 2012: 3). This new great game expression was widely used by geopolitical analysts to refer to energy politics in Central Asia and the Caspian region among great powers such as the United States, China, and Russia and some regional powers like Iran, Turkey, India, and Pakistan. No doubt, end of the Soviet Union left a geopolitical vacuum in very heart of the Eurasian landmass, that is, Central Asia and the adjacent Caspian Sea region, which contains one of the world's richest spoils of untapped natural reserves, especially of gas. Control over this hidden wealth beneath its surface, the transit routes, and the search for new pipelines to get the natural resources out of the landlocked Central Asia attracted the emerging great powers to have political, military, and most importantly economic influence in the region. Moreover, the United States was enjoying the unipolar moment of the 1990s with unmatched hard and soft power. However, dawn of the twenty-first century 
witnessed a geopolitical shift and rebalancing of power in Eurasia from West to East, owing to the relative decline of the United States coupled with the rise of China (Mirza et al. 2020) and resurgence of Russia. These changing dynamics indicated that there is a new round of great game in the town with far more lethal instruments and players than they were in the previous and first round of the great game in the nineteenth century (Kleveman 2003; Rashid 2002b).

\section{China breaking Russia's monopoly}

In the absence of direct Russian control, new regional contenders emerged who were strong enough to make deals with the Central Asian republics on a bilateral basis. The newly born Russian Federation lost the assertive role to dictate who would export what and to whom. Few Central Asian republics such as Turkmenistan, Uzbekistan, and Kazakhstan soon realized that they are now in the position to export their natural resources to other states even if that means allowing foreign countries to invest multi-billion dollars to build new pipelines. Previously, the contestation was mainly between Russia and the West over getting the control and reaching to the Central Asia's oil and gas. However, with China's entry in the Central Asian chessboard resulted in Central Asian natural resources flowing to the east, and not the north and west exclusively.

Currently China has become the largest consumer of crude oil and natural gas (China Surpassed the United States as the World's Largest Crude Oil Importer in 2017 - Today in Energy - U.S. Energy Information Administration (EIA) 2018). As per 2016 statistics, Russia is exporting 58\% of its energy related products to China (Cooley 2015). China also secured admission ticket to Turkmenistan market by receiving the right to explore gas reserves thereby becoming the first country to enjoy such rights (Stronski and Nicole 2018: 13). Today, Turkmenistan is the largest exporter of gas to the Chinese markets thus generates huge amount of revenue. As of October 2019, China has imported a total volume of $252.1 \mathrm{bcm}$ of natural gas from Turkmenistan (Umarov 2020). It had bought almost $60 \%$ of stakes in the company and in the construction of oil pipeline and that too at the expense of Russian and US oil companies (Cooley 2012: 141). Additionally, on one hand the western powers were extending their influence by constructing new pipelines to tap the energy resources in the Caspian Sea and Central Asia. Most notable in this regard is the BP sponsored Baku-Tbilisi-Ceyhan (BTC), a 1000 mile long pipeline functional since 2006, which provides direct access to oil and bypasses not only Russia but Iran too, owning to their relentless opposition to western policies (Bahgat 2006).

On the other hand, China was busy in doing work on construction of their desired network of pipelines. For instance, 'Central Asia-China Gas Pipeline' predates even the Belt and Road Initiative, was launched in 2008 (Overland 2016). This has been China's backbone of cooperation with Central Asia. This pipeline broke Russia's monopoly and significantly reduced its traditional hold of limiting export of Central Asia's oil and gas and also the ability to control exit routes other than Russia 
(Garrison and Abdurahmonov 2011: 382). These western-led and Chinese-led pipelines are bypassing Russia. This indeed had a huge impact on Russia's monopoly diminishing with these transit routes. Moreover, inspired by the success of the first giant project, China and Turkmenistan agreed to sign a supplementary agreement in 2013 for the supply of additional $25 \mathrm{bcm}$ of natural gas. In 2021 China's CNPC signed another agreement of importing $51 \mathrm{bcm}$ of gas in three years, in exchange for helping Turkmenistan increase output of its Galkynysh field (Reuters, 2021). Furthermore, in 2005, the Chinese national company CNPC bought 33 percent stakes for a price of 4 billion dollars from PetroKazakhstan (CNPC Completes Acquisition of PetroKazakhstan, 2005). The next year, China got another contract worth 2 billion dollar to get access to Karazhanba region's oil and gas. According to the estimates, this region has proven reserves of around 340 million barrel (Bhadrakumar 2009: 3). In 2014, as per Business Monitor International (BMI) figures, Turkmenistan total export of gas estimate was around 45 billion cbm, out of which 35 billion cbm went to China (Turkmenistan Boosting Gas Exports to China 2015).

Russia looks uneasy and too wary about the Chinese investments in Central Asia. China also seems uncomfortable with Russia because the 'Central Asia-China Gas Pipeline' passes through Kazakhstan which is member state of the Russianled Eurasia Economic Union (EAEU). This meant that the level of cooperation between Turkmenistan and China depends upon Russia's nod. In order to address this issue, China planned a fourth gas pipeline - Line D - of the Central Asia-China Gas Pipeline, in addition to lines A, B, and C that run parallel. Line D's route will bypass Kazakhstan and move from Turkmenistan, Uzbekistan, Tajikistan, and China (CNPC 2021, Michel 2017). In this regard, China has poured millions of dollars as part of the military aid to strengthen Tajik security forces to be able to protect the pipeline (Kucera 2014). Recently China signed another deal with Tajikistan to build a Chines military base in Tajikistan - ulteriorly with the purpose of fighting terrorism and looking at Afghanistan. But it seems that China wishes to establish its presence in order to secure its investments in Central Asia (Standish 2021).

\section{Conclusion}

In the Sino-Russian relationships, there has emerged some sort of de facto distribution of power whereby Russia continues to enjoy the status of providing the net security umbrella in Central Asia while China plays the role of regional economic integrator. Both Russia and China have made considerable efforts to reassert their mutual control over Central Asia at the expense of American influence. In a nutshell, it is pretty much clear that in the Ukrainian crisis the Obama Administration responded with sanctions on Russia which resulted in the deterioration of Russia-West relations. Later, the Trump Administration triggered trade war with China which resulted in lapsing of the Sino-US relations. As a result, Moscow and Beijing were pushed to come together in the Realist fashion as the old dictum still hold sway; "the enemy of my enemy is my friend." That is exactly what paved the way for the Sino-Russian 
cooperation in Central Asia. But the cooperation demands compromises which puts Russia in a dilemma; Russia is economically weak compared to China which constrains its capacity to develop the region while at the same time it is politically weak too which in turn constrains its ambition to seal the region completely from the expanding influence of the external powers. Thus, Russia and China are forced to cooperate in Central Asia.

But the game of pipeline politics shows conflicting or divergent interests of China and Russia in the region. Both Moscow and Beijing are caught in a situation of mutual suspicions whereby Beijing desperately looks for new areas of energy to satisfy its growing and expanding domestic needs while Moscow looks for alternative approach to reestablish its dominant role and control over natural resources in the region. In between, Turkmenistan needs emerging markets to export and generate massive amount of budget revenues out of its natural gas reserves. Fortunately, the crisis in Ukraine provided a sought-after opportunity for Turkmenistan to eventually get access to the European market, previously dependent on Russia, for export of its natural resources. Most notable development in this regard is the proposed construction of the 'Trans-Caspian Gas Pipeline' (TCGP) which will deliver gas from Turkmenistan to Azerbaijan and Georgia where it will meet the 'Trans-Anatolian Natural Gas Pipeline' via Turkey and then finally to Europe (Rahimov 2019). This project is largely supported by the United States and the European Union while simultaneously opposed by Russia and Iran who have cited ecological consequences for the Caspian Sea (Aghai Diba 2018). The United States wants to decrease and eventually diminish Russia's long-held monopoly over export of natural resources of Central Asia to Europe and elsewhere. Additionally, the United States wants to severely hit Russia's economic power which may put a halt on its geopolitical ambitions not only in the region but elsewhere too, particularly in the Middle East. As for the European powers, their only concern and national interest is to search out for new markets to diversify its energy imports which would decrease its dependence on Russia. In all this tug of war, China remains the winner, who emerged as the biggest importer of the natural gas from Central Asia in the recent years.

Addresses:

Muhammad Nadeem Mirza

School of Politics and International Relations

Quaid-i-Azam University

Islamabad 45320, Pakistan

E-mail: mnadeemmirza@qau.edu.pk

Shaukat Ayub

School of Politics and International Relations

Quaid-i-Azam University

Islamabad 45320, Pakistan 


\section{References}

Abbas, S. (2012) “Ip and Tapi in the 'New Great Game': can Pakistan keep its hopes high?”. Institute of Regional Studies (Islamabad) 31, 4, 38.

Aghai Diba, B. (2018) "Iran and the trans-Caspian gas pipeline". Payvand Iran News, January 18. Available online at $<$ http://www.payvand.com/news/18/jan/1030.html $>$. Accessed on 07.08.2021.

Ahrari, E. (2003) "The strategic future of Central Asia: a view from Washington". Journal of International Affairs 56, 2, 157-166.

Allison, G. (2018) “The myth of the liberal order". Foreign Affairs 97, 4, 207.

Bahgat, G. (2006) "Central Asia and energy security”. Asian Affairs 37, 1, 1-16.

Bhadrakumar, M. K. (2009) "China resets terms of engagement in Central Asia: energy and great power conflict”. The Asia-Pacific Journal: Japan Focus 7, 52, 1-10.

Blank, S. (1995) Energy, economics and security in Central Asia: Russia and its rivals. Central Asian Survey 14, 3, 373-406. DOI: https://doi.org/10.1080/02634939508400913

"China surpassed the United States as the world's largest crude oil importer in 2017". Today in Energy. U.S. Energy Information Administration (EIA) (2018) Available online at $<$ https://www.eia. gov/todayinenergy/detail.php?id=37821\#

Chung, C. (2004) "The Shanghai Co-operation Organization: China's changing influence in Central Asia". The China Quarterly 180, 989-1009.

Clarke, M. (2010) "China and the Shanghai Cooperation Organization: the dynamics of new 'regionalism', 'vassalization', and geopolitics in Central Asia”. In Emilian Kavalski, ed. The New Central Asia: the regional impact of international actors, 117-147. Singapore: World Scientific Publication Co.

CNPC (2021) Flow of natural gas from Central Asia. China National Petroleum Corporation. Available online at $<$ https://www.cnpc.com.cn/en/>. Accessed on 17.11.2021.

CNPC completes acquisition of PetroKazakhstan (2005) China Daily, October 27. Available online at $<$ http://www.chinadaily.com.cn/english/doc/2005-10/27/content_488314.htm $>$. Accessed on 07.08.2021.

Cooley, A. (2012) Great games, local rules: the new power contest in Central Asia. Oxford University Press.

Cooley, A. (2015) Russia and China in Central Asia. Norwegian Institute for International Affairs (NUPI).

EAEU (2014) Eurasian Economic Union. Available online at <http://www.eaeunion.org/?lang=en\#/>. Accessed on 17.11.2021.

Felicitas, S. (2019) “China Belt and Road Initiative: Pan-Asia Railway gains momentum”. AsiaFundManagers, May 29. Available online at $<$ https://www.asiafundmanagers.com/int/china-beltand-road/>. Accessed on 07.08.2021.

Gabuev, A. (2016) “Crouching bear, hidden dragon: 'One Belt One Road' and Chinese-Russian jostling for power in Central Asia". Journal of Contemporary East Asia Studies 5, 2, 61-78.

Garnett, S. (2001) "Challenges of the Sino-Russian strategic partnership". The Washington Quarterly $24,4,41-54$.

Garrison, J. A., and A. Abdurahmonov (2011) "Explaining the Central Asian energy game: complex interdependence and how small states influence their big neighbors". Asian Perspective 35, 3, 381-405.

Harper, T. (2019) "China's Eurasia: the Belt and Road Initiative and the creation of a new Eurasian power”. The Chinese Journal of Global Governance 5, 2, 99-121. 
Hart, Michael (2016) "Central Asia's oil and gas now flows to the East". The Diplomat, August 18. Available online at $<$ https://thediplomat.com/2016/08/central-asias-oil-and-gas-now-flows-tothe-east/>. Accessed on 07.08.2021.

Hast, S. (2014) Spheres of influence in international relations: history, theory and politics. Routledge. Huasheng, Z. (2013) "China's view of and expectations from the Shanghai Cooperation Organization". Asian Survey 53, 3, 436-460.

Jiang, Y. (2020) "Russia's strategy in Central Asia: inviting India to balance China". The Diplomat, January 23. Available online at $<$ https://thediplomat.com/2020/01/russias-strategy-in-centralasia-inviting-india-to-balance-china/>. Accessed on 07.08.2021.

Kleveman, L. (2003) The New Great Game: blood and oil in Central Asia. New York: Grove Press.

Kucera, J. (2014) "China promises Tajikistan 'hundreds of millions of dollars"'. In Military Aid. Eurasianet. Available online at $<$ https://eurasianet.org/china-promises-tajikistan-hundreds-ofmillions-of-dollars-in-military-aid $>$. Accessed on 17.11.2021.

Lanteigne, M. (2005) China and international institutions: alternate paths to global power. London: Routledge.

Lanteigne, M. (2008) "China's maritime security and the "Malacca dilemma". Asian Security 4, 2, 143-161. DOI: https://doi.org/10.1080/14799850802006555

Lo, B. (2008) Axis of convenience: Moscow, Beijing, and the new geopolitics. Brookings Institution Press. Maynes, C. W. (2003) “America discovers Central Asia”. Foreign Affairs 82, 2, 120-132.

Mearsheimer, J. J. (2016) "Structural realism”. In T. Dunne, M. Kurki, and S. Smith, eds. International relations theories: discipline and diversity, 359. 4th ed. Oxford University Press.

Menon, R. (1997) "The strategic convergence between Russia and China”. Survival 39, 2, 101-125.

Menon, R. (2003) “The New Great Game in Central Asia”. Survival 45, 2, 187-204. DOI: https://doi. org/10. 1080/00396338.2003.9688581

Michel, C. (2017) “The Central Asia-China gas pipeline network: Line D(ead)". The Diplomat, March 21. Available online at $<\mathrm{https} / /$ thediplomat.com/2017/03/the-central-asia-china-gaspipeline-network-line-dead/>. Accessed on 07.08.2021.

Mirza, M. N., H.,Abbas, and M. Q. Nizamani (2020) "Evaluating China's soft power discourse: assumptions, strategies, and objectives". Global Strategic and Security Studies Review 5, 4, 40-50. DOI: https://doi.org/10.31703/gsssr.2020(V-IV).05

Mirza, M. N., H. Abbas, and I. H. Qaisrani (2021) "Structural sources of Saudi-Iran rivalry and competition for the sphere of influence". Sage Open 11, 3, 21582440211032640. DOI: https://doi.org/10.1177/21582440211032642

Mirza, M. N. and F. Z. Khan (2020) "Systemic transformations and Chinese image of the world order: transcending Great Wall through Neo-Confucianism and Tianxia systems". Asia Pacific 38, 22-38.

Moisio, S. (2019) "Re-thinking geoeconomics: towards a political geography of economic geographies". Wiley Online Library. Geography Compass 13, 10, e12466. DOI: https://doi.org/10.1111/ gec3.12466

Muzalevsky, R. (2012) “China-Kyrgyzstan-Uzbekistan railway scheme: fears, hopes and prospects". Eurasia Daily Monitor, May 30, 9, 102.

Norling, N. (2007) "China and Russia: partners with tensions". Policy Perspectives 4, 1, 33-48.

Overland, I. (2016) "Energy: the missing link in globalization”. Energy Research \& Social Science 14, 122-130. 
Parkhomchik, L. (2016) China-Kazakhstan relations in the oil and gas sector. Eurasian Research Institute. Available online at <https://eurasian-research.org/publication/china-kazakhstanrelations-in-the-oil-and-gas-sector/>. Accessed on 07.08.2021.

Rahimov, R. (2019) "Prospects for the Trans-Caspian gas pipeline under the Trump administration". Wilson Center. Available online at $<\mathrm{https}$ ://www.wilsoncenter.org/blog-post/prospects-for-thetrans-caspian-gas-pipeline-under-the-trump-administration>. Accessed on 07.08.2021.

Rashid, A. (2002a) Jihad: the rise of militant Islam in Central Asia. Yale University Press.

Rashid, A. (2002b) Taliban: Islam, oil and the new great game in central Asia. London and New York: I. B. Tauris. (1st ed., 2000.)

Reuters (2021) “China's CNPC secures more Turkmen gas in new deal - source”. Reuters, August 24. Available online at $<$ https://www.reuters.com/world/middle-east/chinas-cnpc-secures-51-bcmturkmen-gas-new-deal-says-source-2021-08-23//>. Accessed on 17.11.2021.

Romanowski, M. (2017) "Decoding Central Asia: what's next for the US administration?" The Diplomat, February 28). Available online at $<$ https://thediplomat.com/2017/02/decodingcentral-asia-whats-next-for-the-us-administration/>. Accessed on 07.08.2021.

Sahai, D. (2019) "Russian Far East and Central Asia: impediments to Sino-Russian partnership". Observer Research Foundation 280, 20.

Shambaugh, D. (2013) China goes global: the partial power. Oxford University Press.

"Shanghai Five" nations sign joint statement. (2000) People’s Daily, July 6. Available online at $<$ http:// en.people.cn/200007/06/eng20000706_44803.html>. Accessed on 07.08.2021.

Shanghai-5 (1998) "Letter dated 9 July 1998 from the Permanent Representatives of China, Kazakhstan, Kyrgyzstan, the Russian Federation and Tajikistan to the United Nations addressed to the Secretary-General". United Nations. Available online at $<\mathrm{https}$ ://undocs.org/ pdf?symbol=en/A/52/978>. Accessed on 17.11.2021.

Shimbun, A. (2017) "Graham Allison: avoiding a Sino-American war [interview]". Available online at $\quad<$ https://www.belfercenter.org/publication/graham-allison-avoiding-sino-american-war>. Accessed on 07.08.2021.

Standish, R. (2021) "Tajikistan approves new Chinese base as Beijing's security presence in Central Asia grows". Radio Free Europe/Radio Liberty, October 28. Available online at $<$ https://www. rferl.org/a/tajikistan-approves-chinese-base/31532078.html>. Accessed on 17.11.2021.

Stronski, P., and N. Nicole (2018) "Cooperation and competition: Russia and China in Central Asia, the Russian Far East, and the Arctic”. Carnegie Endowment for International Peace 1-49.

Treaty of Good-Neighborliness and Friendly Cooperation Between the People's Republic of China and the Russian Federation (2001) Ministry of Foreign Affairs of the People's Republic of China, July 24. Available online at <https:/www.fmprc.gov.cn/mfa_eng/wjdt_665385/2649_665393/ t15771.shtml>. Accessed on 07.08.2021.

“Turkmenistan boosting gas exports to China" (2015) Hydrocarbon Engineering, February 11. Available online at $<$ https://www.hydrocarbonengineering.com/gas-processing/11022015/Turkmenistanboosting-gas-exports-to-China-230/>. Accessed on 07.08.2021.

Umarov, T. (2020) "China Looms Large in Central Asia". Carnegie Moscow Center, March 30. Available online at $<$ https://carnegie.ru/commentary/81402>. Accessed on 07.08.2021.

Zhao Lei (2019) "Xi vows to fight 'three evil forces' of terrorism, separatism and extremism". The Telegraph, April 26. Available online at $<$ https:/www.telegraph.co.uk/china-watch/politics/xifights-three-evil-forces-terrorism-separatism-extremism/>. Accessed on 07.08.2021. 